\title{
A Educação Metodista e seus aspectos Teológicos Pastorais
}

\author{
Orientador: Luís Corrêa Lima \\ Mestranda: Gláucia Mendes Oliveira Silvestre \\ Área de Concentração: Teologia Sistemático-Pastoral \\ Linha de Pesquisa: Religião e Modernidade
}

Refletir sobre a Teologia da Educação Metodista é um tema muito rico e amplo. Pode ser analisado e compreendido por vários olhares. Obviamente o assunto não será esgotado mas serão destacados os aspectos mais relevantes desta discussão.

Desde o início do movimento metodista na Inglaterra, no séc. XVIII, John Wesley, seu principal pioneiro, demonstrava especial atenção à educação, à vida piedosa, bem como às ações humanitárias na tentativa de alcançar e responder as necessidades do ser humano de sua época de forma integral.

Sua formação acadêmica foi na conceituada Universidade de Oxford. Dedicava-se à busca do conhecimento associando-o sempre à fé cristã e à prática do amor ao próximo.

$\mathrm{O}$ resultado da dedicação deste homem se espalhou por toda a parte através da ação missionária do Movimento Metodista onde, entre tantas coisas, fundou milhares de escolas. Nesses mais de 250 anos de educação metodista, somente nos EUA e Inglaterra foram erguidas 1.900 escolas.

O ponto principal desta dissertação é a rica oportunidade de refletir sobre os rumos e a relevância da educação metodista no Brasil hoje, através de suas instituições de ensino considerando a trajetória histórica a partir de seu fundador John Wesley.

Palavras-chave: Movimento Metodista; Missão; Pastoral. 